\section{Some personal reminiscences of the Institute of Archaeology, 1933-62 Rachel Maxwell-Hyslop}

Rachel Maxwell-Hyslop (Fig. 1) was one of the first three students to be admitted to the Institute, in 1934, even before it had a building, and she later joined the staff as a member of the Department of Western Asiatic Archaeology. She recalls her early teachers and her later work with Max Mallowan and other colleagues during the formative years of the Institute.

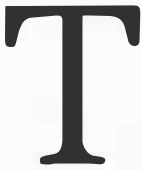

e origins of the Institute of Archaeology go back to 1933/34 when Mortimer Wheeler was lecturing on British archaeol-

ogy at the London Museum, of which he was then Director. I attended his lectures, as did Stuart Piggott (who was later to succeed Gordon Childe as Abercromby Professor of Archaeology at Edinburgh). ${ }^{1}$ By 1934 I already had experience of working for Wheeler, cleaning Roman pavements at Verulamium and digging Neolithic pits at Maiden Castle, and this had convinced me that my real interest in archaeology lay outside Europe.

Egyptology, I thought, was the answer. At UCL the Edwards Professor of Egyptology, Stephen Glanville, said "Yes, of course, come in October". Then, after a pause, he added "but if you really want my advice, don't read Egyptology. Why not go for the new course in Mesopotamian archaeology? No one has ever taken it, but it is listed in the University of London Green Book and if students appear then teaching will have to be provided." $\mathrm{He}$ must have known that Wheeler was engaged in negotiations for founding an institute of archaeology and that a new course with potential students would help to convince the university of the need for an institute.

A preliminary interview with Sidney Smith, Keeper of Egyptian and Assyrian Antiquities at the British Museum and Honorary Lecturer in Akkadian and Assyriology at King's College London, was essential before one could be accepted for the new course. The interview was short and alarming. He made it clear that one should have studied classics before even thinking of Near Eastern archaeology. I remember his first question, "Of course you can read French, German and Italian fluently?". Bluff seemed the only hope, when truthfully the answer should have been French, yes, Italian, one year at school, and German, none. But I calculated that there were five months before the beginning of the academic year and time for intensive study of German. So I said "Yes".

In 1934, Barbara Parker (later Lady Mallowan) and Flora Beck, who was bilingual in German and English, had also been accepted. Although at first unwilling, Sidney Smith agreed both to define and be responsible for the teaching of the new and elementary surveying for archaeolo-

Figure 1 Rachel Maxwell-Hyslop, 1998. course. He was appointed Honorary Lecturer in 1934 (and Honorary Professor in 1938) in Near Eastern Archaeology at the fledgling Institute. His twice weekly classes were held in the evenings at the British Museum, and first-year Akkadian was provided by S. H. Hooke, Professor of Old Testament Studies at King's College. A single shelf of books on Mesopotamian history, language and archaeology was housed in the Box Library at King's, where we were allowed to work, to the annoyance of several of the staff of the Department of Theology, as they were already very short of space. UCL provided weekly classes in ancient history, taught by Professor Norman Baynes, as well as some anthropology,

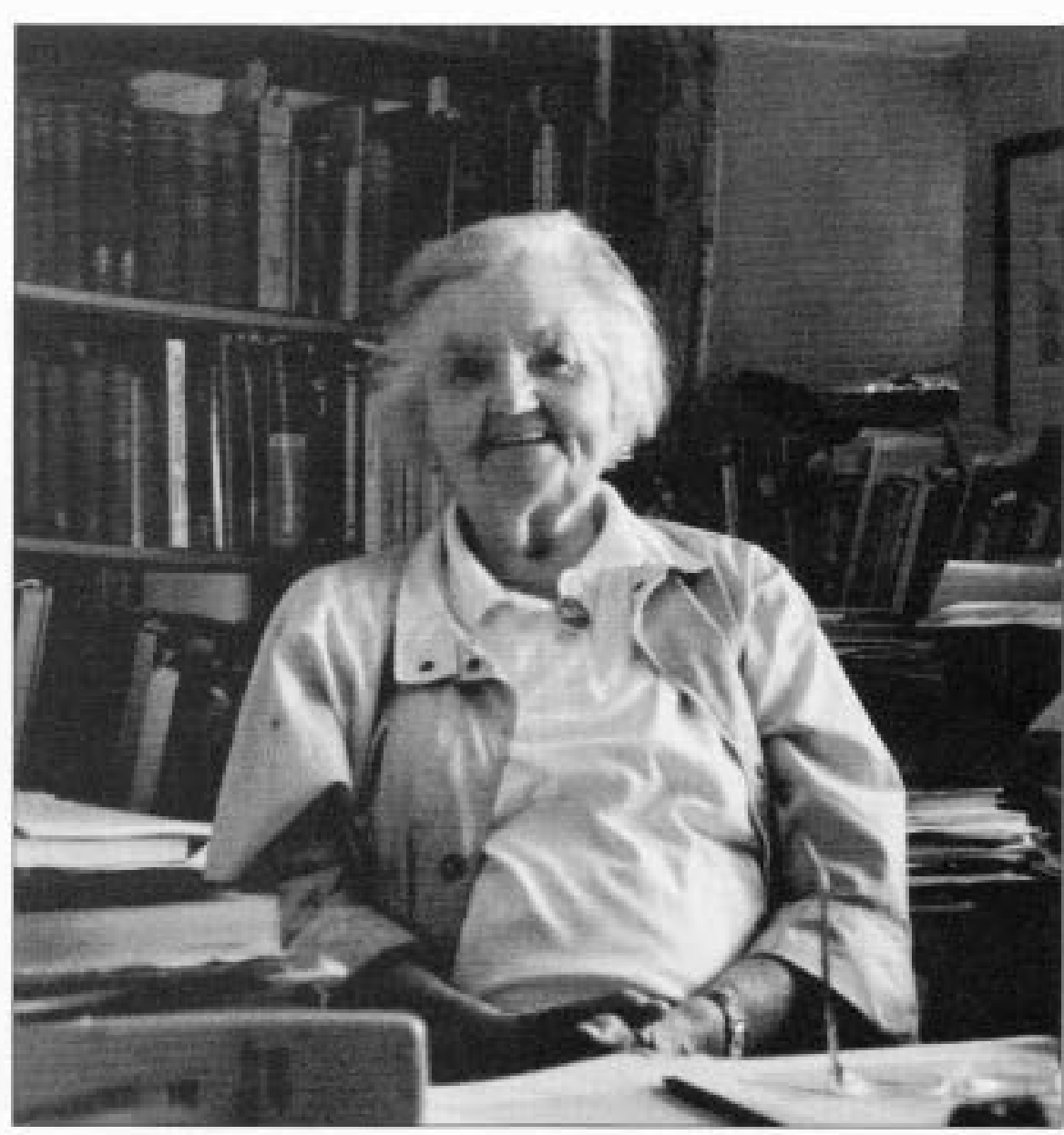

gists which consisted of a detailed survey, by plane table and theodolite, of the front quadrangle at UCL. Long sessions in the British Museum Reading Room, where we seemed to spend a large part of the vacations, were essential. There, we soon learned that a request for Layard's $\mathrm{Ni}$ neveh, ${ }^{2}$ which arrived on a trolley, gained us entry to the North Library, which was an ideal place to work.

Sidney Smith has been described as the architect of Mesopotamian studies ${ }^{3}$ and the statement that "he never spared himself or his students" can certainly be confirmed, not only by his first three pupils (Flora Beck, Barbara Parker and myself) but also by Margaret Munn-Rankin, later Lecturer in Near Eastern Archaeology at Cambridge, and Professor Donald Wiseman of London's School of Oriental and African Studies, who both studied with Smith after the Second World War. His method of teaching was both stimulating and demanding. He constantly emphasized the importance of assessing every kind of evidence - historical, archaeological, architectural, pottery, metalwork, etc. - and of linking it to economic, religious, mythological and legal texts (such as Hammurabi's Law Code), while also condisering technical, scientific and artistic problems. Literary texts, archaeology 
and language were thus inextricably linked and could provide evidence not only of material culture but of people's everyday lives. ${ }^{4}$

After its establishment on paper the Institute acquired its first home, St John's Lodge in Regent's Park, which was formally opened in April 1937. ${ }^{5}$ Barbara Parker and I had been appointed Honorary Demonstrators while I was excavating with Winifred Lamb at Kusura in Turkey and Barbara had joined J. L. Starkey at Lachish in Palestine. But the war intervened; Barbara went to Baghdad as Secretary to the British School of Archaeology in Iraq and I joined the staff of the Institute in 1946 just before Gordon Childe moved from Edinburgh to take up his appointment as Director (see the following article by Nancy Sandars on Gordon Childe at St John's Lodge). Max Mallowan arrived in April 1947 as Prof essor of Western Asiatic Archaeology, with myself as Assistant and then Lecturer, both part-time posts. With Kathleen Kenyon's appointment in January 1948 as Lecturer in Palestinian Archaeology and Curator of the Petrie Palestinian Collection, ${ }^{6}$ the foundations were laid for the subsequent expansion and achievements in western Asiatic archaeology at the Institute. Western Asia naturally attracted many students from overseas. Among the first were Yigael Yadin from Israel, Tariq Madlhoom from Iraq and F. A. Durrani from Pakistan. Georgina Herrmann and Harriet Crawford were also among the early recruits.

Working with Mallowan was both stimulating and exciting. Excavation at Nimrud (in Iraq) continued during each Easter term (Fig. 2); the study collections of material from Mesopotamia, Syria, Cyprus, Anatolia, Iran and Palestine were rearranged; Olga Tufnell worked on the Lachish material; and Kathleen Kenyon continued to direct the excavations at Jericho. The importance of Anatolia in western Asiatic archaeology was recognized, and James Mellart was appointed Lecturer in Anatolian Archaeology (in 1964).

During the years 1947-62 the Institute Librarygrew under the guidance of Joan du Plat Taylor as Librarian. The scientific work also expanded in geochronology and environmental archaeology, pioneered by Frederick Zeuner, and in materials science and conservation, led by Henry Hodges and Ione Geyde. My interest in metal was stimulated by my being sent to the laboratory by Mallowan "to find out about their restorative and analytical work" and to suggest objects from the Institute's collections that could be examined and published. ${ }^{7}$ Initially, a shortage of materials for the lab was solved by Gordon Childe giving me $£ 5$ to go and buy some Luristan bronzes that I had seen in the window of an oriental carpet shop in Notting Hill. In addition to the bronzes, I also managed to obtain, as a gift, an Iranian iron sword hilt decorated with two seated lions and a pair of bearded human heads. In order to show conclusively how it had been made, Henry Hodges, in cooperation with Vera Bird of the British Museum Research Laboratory, decided to cut the hilt in half longitudinally. This caused great interest in the British Museum, whereit was exhibited, as no museum could ever consider itself carrying out such an operation. ${ }^{8}$

Apart from teaching, excavation, technical and scientific studies, publication was regarded as especially important. Mallowan's account of the years 1947-62 ${ }^{9}$ gives a comprehensive list of books and articles in learned periodicals published by the three members of the Department of Western Asiatic Archaeology, starting with the Institute's first Occasional Paper. ${ }^{10}$ It is worth noting that in 1962, after 15 years of teaching at the Institute, Mallowan still insisted that students should have "some familiarity with ancient languages, history, literature and religion, which is inseparable from the study of Oriental archaeology", thus endorsing the requirements first expressed by Sidney Smith in 1934.

\section{Notes}

1. S. Piggott, "Robert Eric Mortimer Wheeler, 10 September 1890-22 July 1976", Biographical Memoirs of Fellows of the Royal Society 23, 625-42, 1977.

2. A. H. Layard, Nineveh and its remains, 2 vols (London: John Murray, 1850).

3. D. J. Wiseman, "Sydney Smith 18891979", Proceedings of the British Academy 667, 463-71, 1980.

4. For example, references in Mesopotamian texts to such mundane incidents as complaints about the high price of lapis lazuli or the difficulties of taking clothes to the cleaners in Ur in the second millennium BC. See C. J. Gadd, "Two sketches from the life at Ur “, Iraq 25, 177-88, 1963, and A. L. Oppenheim, Letters from Mesopotamia: official business and private letters on clay tablet from two millennia (Chi cago: University of Chicago Press, 1977).

5 . The history of the Institute is briefly

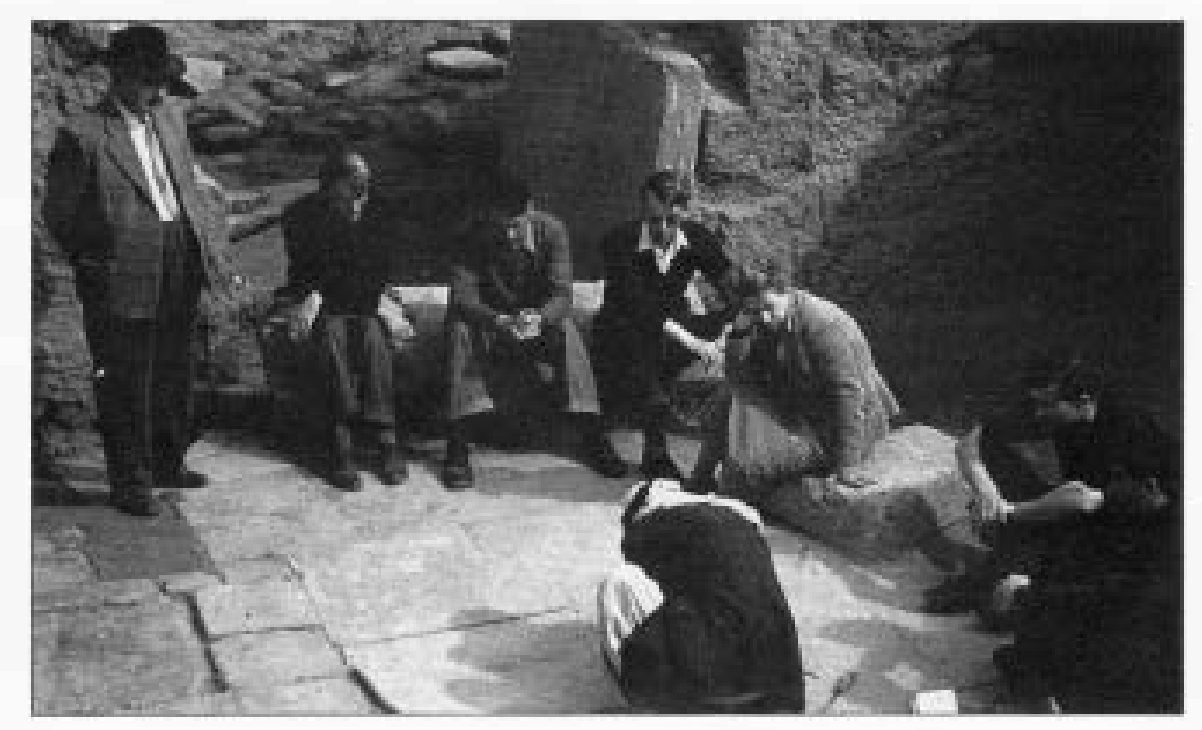

Figure 2 Max Mallowan (left) with some of his excavation supervisors and his Arab

foreman at the Nabu temple, Nimrud, in the 1950s. described by D. R. Harris in "Sixty years 97", Archaeology International 1997/98, $3-5$, and in greater detail by J. D. Evans in "The first half century - and after", Bulletin of the Institute of Archaeology 24, 1-25, 1987.

6. Kathleen Kenyon had been appointed Secretary of the Institute in 1935 and Acting Director in 1942 (while Wheeler was serving with the Eighth Army in North Africa and Italy). In 1948 she resigned as Secretary and accepted the Lectureship in Palestinian Archaeology.

7. K. R. Maxwell-Hyslop, with a technical report by H. W. M. Hodges, "Bronzes from Iran in the collections of the Institute of Archaeology, University of London", Iraq 24, 126-33, 1962; K. R. Maxwell-Hyslop \& H. W. M. Hodges, "A note on the significance of the technique of 'casting on' as applied to a group of daggers from northwest Persia" Iraq 26, 50-3, 1964.

8. See K. R. Maxwell-Hyslop \& H. W. M. Hodges. "Three iron swords from Luristan", Iraq 28, 164-76, 1966 and V. Bird \& H. Hodges, "A metallurgical examination of two early iron swords from Luristan", Studies in Conservation 13, 215-33, 1968. Our suggested date for the sword hilt (late 11th to early 10 th centuries $\mathrm{BC}$ ), based on technical and historical evidence, has recently been confirmed by J. E. Rehder, working on two similar Iranian swords in the Royal Ontario Museum and the Massachusetts Institute of Technology where radiocarbon dates were obtained of the wood from which the charcoal was made for smelting the iron; see J. E. Rehder, "The decorated iron swords from Luristan: their material and manufacture", Iran $\mathbf{2 9 ,}$ 13-19, 1991 Inaugural lecture", Fourth Annual Report 1946-7, University of London Institute of Archaeology.

10. K. R. Clay (Maxwell-Hyslop), The tenure of land in Babylonia and Assyria (University of London Institute of Archaeology Occasional Paper No. 1, 1938, now out of print). on: the Institute of Archaeology, 1937-

9. M. E. L. Mallowan, "The legacy of Asia. 